\title{
The Convalescent Plasma Craze! Where Does India Stand?
}

\author{
Arcot J Priyadarsini ${ }^{1} \quad$ Kumar Karan ${ }^{1} \quad$ Subramanian Arulselvi ${ }^{2, \odot}$ \\ ${ }^{1}$ Department of Transfusion Medicine, AlIMS, New Delhi, India \\ 2Department of Laboratory Medicine \& Blood Bank, Jai Prakash \\ Address for correspondence Arulselvi Subramanian, MD, \\ Narayan Apex Trauma Centre, New Delhi, India \\ Department of Laboratory Medicine \& Blood Bank, Jai Prakash \\ Narayan Apex Trauma Centre, New Delhi, India \\ (e-mail: arulselvi.jpnatc@gmail.com).
}

J Lab Physicians 2021;13:183-191.

\begin{abstract}
India becomes the country with second highest number of coronavirus disease 2019 (COVID-19) cases $(59,03,932)$ as of September 2020 . As the world debates various treatment options, the current pandemic has led to the resurgence of an ancient technique, namely convalescent plasma therapy. Although it has been in use from

Keywords

- COVID-19

- convalescent plasma

- India

- challenges the late 19th century, it is an uncharted territory for most developing nations. In this article, we have discussed the pros and cons of convalescent plasma transfusion in COVID-19 patients. Articles discussed in this review have been obtained from search engines, namely PubMed, Scopus, and Embase. We have also expressed our viewpoint on the feasibility and logistical challenges of convalescent plasma use in India.
\end{abstract}

\section{Key Message}

The right and wrong regarding the usage of convalescent plasma are yet to be solved. Building enthusiasm must be dealt cautiously to prevent the promotion of paid donation in India.

\section{Introduction}

The current coronavirus disease 2019 (COVID-19) pandemic has been talked about for more than 8 months now. Highlights are the novelty of the virus and the unpreparedness of even the most developed nations. Viruses of the $\beta$-coronavirus genus commonly cause mild respiratory infection. ${ }^{1}$ But the previous two pandemics caused by severe acute respiratory syndrome coronavirus (SARS-CoV) in 2002 and the Middle East respiratory syndrome coronavirus (MERS-CoV) in 2012 were exceptions, as the strains became highly pathogenic and virulent on crossing the species barrier. ${ }^{2}$ The SARS-CoV-2 genomically resembles SARS-CoV, ${ }^{3}$ but differs in two aspects, namely better prognosis (except in older patients with comorbidities) and higher transmission rate. ${ }^{4-6}$ Symptoms can be mild published online June 16, 2021
DOI https://doi.org/ $10.1055 / \mathrm{s}-0041-1730753$ ISSN 0974-2727 (fever, cough, myalgia, fatiguability, dyspnea) to severe (respiratory distress, multiorgan failure, immunomodulatory effects, coagulopathy) and sometimes even be fatal. ${ }^{6-8}$ Although this is the third pandemic by coronavirus, there are no approved treatment options. From retrying pre-existing and native medicines to the development of newer-options/vaccines, mankind has left no stone unturned. ${ }^{9,10}$ Convalescent plasma (CP) is one of the treatment options amply debated. $\mathrm{CP}$ refers to plasma obtained from a recently cured individual with an aim to harvest capable levels of antibodies directed against the causative agent. Theoretically, they can be used as treatment as it will prevent disease progression by offering short-term/passive immunity ${ }^{11}$ or as prophylaxis. ${ }^{12}$ Its role in active immunity has also been observed. ${ }^{13}$ Along with neutralizing antibodies, other anti-inflammatory substances (defensins, non-neutralizing antibodies, etc.) provide further immunomodulatory benefits. ${ }^{14}$ Antibody transfer dates back to 1890s when Emil von Behring used CP against bacterial toxins before the discovery of antimicrobials for which he received the Nobel Prize..$^{15}$ The current pandemic has led to resurgence of this ancient technique ( - Fig. 1). In this review, (c) 2021. The Indian Association of Laboratory Physicians.

This is an open access article published by Thieme under the terms of the Creative Commons Attribution-NonDerivative-NonCommercial-License, permitting copying and reproduction so long as the original work is given appropriate credit. Contents may not be used for commercial purposes, or adapted, remixed, transformed or built upon. (https://creativecommons.org/licenses/by-nc-nd/4.0/). Thieme Medical and Scientific Publishers Pvt. Ltd. A-12, 2nd Floor, Sector 2, Noida-201301 UP, India 


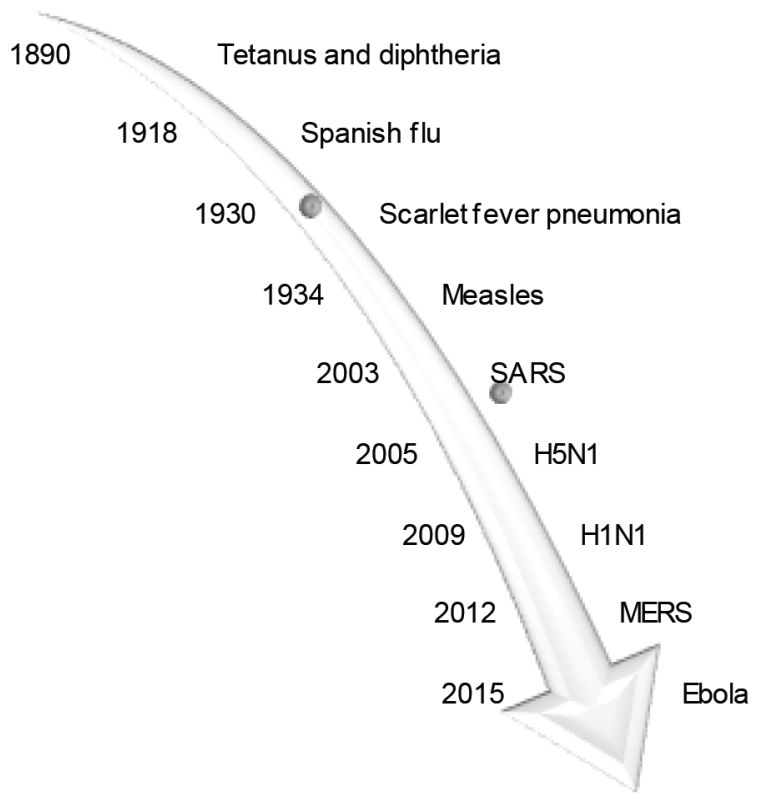

Fig. 1 Convalescent plasma-an ancient technique.

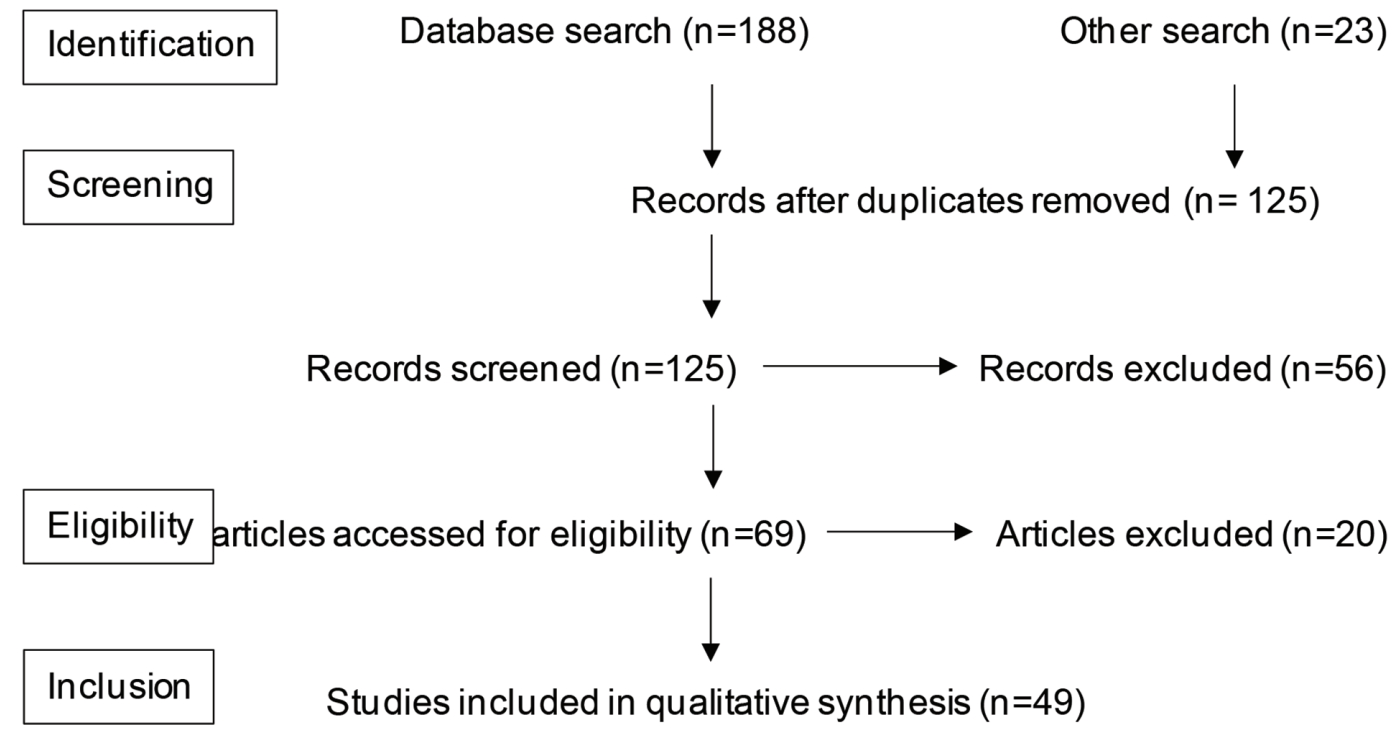

Fig. 2 Preferred Reporting Items for Systematic Reviews and Meta-Analyses (PRISMA) flow for study inclusion.

we discuss the past and present experience with $\mathrm{CP}$ and the Indian challenges with respect to logistics and feasibility. Articles discussed in this review have been obtained from various search engines, namely PubMed, Scopus, and Embase till September 20, 2020 as shown in -Fig. 2.

\section{Previous Experience}

Case reports and series have been published on the beneficial effect of CP in SARS-CoV-1, MERS-CoV emphasizing its use in the earlier phase of disease, lack of serious adverse effects, donor group to be targeted for harvest (recovered patients who were symptomatic during the time of illness), collection timing (antibody titer decreases as the time after recovery increases), and the most beneficial patient group (young patients with mild disease). ${ }^{16-18}$ Quality research was not possible during the outbreak of Ebola as it mainly affected lower economic geography. However, an immediate decrease in viral load was observed in patients who received CP as an additional treatment. ${ }^{19}$ Due to the devastating nature of the virus, the World Health Organization (WHO) went ahead and recommended the use of CP in treating ebola. ${ }^{20}$ The use of $\mathrm{CP}$ was also studied in patients with influenza ${ }^{21}$ and other viral hemorrhagic fevers. ${ }^{22}$ 
From previous experiences, two things are clear. First, there is evidence on the potential benefits of CP against various infectious diseases. Second, there is no literature about $\mathrm{CP}$ use from India. Hence, Indian setups are quite new to this territory that will give rise to newer challenges.

\section{CP in COVID-19 Pandemic}

Typically, during the earlier phase of the disease, antispike antibodies (inducing apoptosis) are produced. Only during the later phase, antinucleocapsid antibodies (neutralization) are produced. Most of the published case series, ${ }^{23,24}$ randomized, ${ }^{25}$ and matched-controlled trials $^{26}$ have had good outcomes (symptomatic/radiological resolution, lymphocyte count, viremia) with minimal side effects emphasizing its use in the earlier phase of the disease. But few have questioned its actual role in reducing disease mortality. ${ }^{27}$ Also, the routine use of CP may suppress the patient's humoral immunity ${ }^{28}$ and may lead antibody-dependent enhancement of the disease ${ }^{29}$ that should be kept in mind.

The side effects of $\mathrm{CP}$ are similar to routine plasma transfusion. A susceptible-exposed-infected-removed model-based risk-benefit analysis was used to compare the benefit of $\mathrm{CP}$ and its transfusion-associated risk from the available literature. In simple words, the authors concluded that the mortality due to the disease is more than the mortality due to $\mathrm{CP}$ administration. ${ }^{30}$

Finally, the Cochrane Library of reviews that compared the efficacy and safety of CP versus hyperimmune immunoglobulin (HIIG) concluded the uncertainty of CP's effect due to low-quality evidence till date and is waiting for results comparing the two from ongoing studies. ${ }^{31}$ Based on the available evidence, it is only clear that $\mathrm{CP}$ does not cause any serious side effects. Hence, CP was approved as an emergency investigational new drug by the United States' Food and Drug Administration (FDA) on August 23, 2020 and later three types of access to $\mathrm{CP}$ were established, namely compassionate use (for life-threatening illness), clinical trials, and expanded access. ${ }^{32}$ FDA does not allow its use for prophylaxis. It calls for further high-quality studies. A comparison of the three major guidelines, namely American, European, and International Society of Blood Transfusion (ISBT) is shown in - Table 1.

\section{Studies Till Now}

Till now studies have had different objective/s, population type (mild/ moderate/severely ill-patients/mixture), timing of administration (prophylactic/earlier/later), and with/without a control group (exclusive benefit). The control group can receive random donor plasma or standard care. Aspects such as wastage of plasma, transfusion-related side effects, and beneficial effects of routine plasma must not be forgotten.

The ultimate end point measured will depend on population type. For instance, symptomatic/radiological improvement and pulmonary function status will be the end point in hospitalized noncritically ill patients. But for ventilated/patients admitted in intensive care unit (ICU), death will be the end point. Secondary end points shall range from duration of hospital/ICU stay, cost incurred, antibody titers, viral load, and end-organ failure. With unlimited number of published material and ongoing studies, it is becoming difficult to conclude on the role of CP. Broadly, the studies can be divided into three types.

1. Role of $\mathrm{CP}$ in postexposure prophylaxis: Study subjects are those exposed to virus but yet to develop symptoms. End point will be "patients testing positive." Such studies will show the effect of CP as post-exposure prophylaxis in high-risk groups (health-care workers, elderly with comorbidities). No studies of this type have been published till date.

2. Role of $\mathrm{CP}$ in halting disease progression: The effect of CP when transfused in patients with mild (end pointhospital stay/disease progression/oxygen requirement) or moderate disease (end point-progression to critical disease/intubation). Encouraging results have been obtained in mild-to-moderate illness. ${ }^{33}$

3. Role of $\mathrm{CP}$ as a last/rescue option: Results are unreliable due to several confounding factors (received/receiving other treatment/already developed antibody). End point will be death. Although studies have proved the safety and beneficial effect of CP in severe/critically ill patients, ${ }^{34,35}$ some have shown that the benefit is obtained only when the $\mathrm{CP}$ is administered during the earlier phase of illness. ${ }^{36,37}$

\section{Indian Scenario}

Although the second interim guidelines by National Blood Transfusion Council (NBTC) did not recommend the routine use of $\mathrm{CP}^{38}$ the recent advisory by Central Drugs Standard Control Organization has indicated CP as off-label therapy in patients not improving with steroids. ${ }^{39}$ As of now, 12 registered clinical trials on CP are ongoing. ${ }^{40}$ Indian Council of Medical Research (ICMR) in collaboration with other health centers conducted the PLACID (open label phase II multicentre randomized controlled) trial. ${ }^{41}$ Although this is the largest study in the country involving 46 centers, it represents the finding of real-time setups with limited resources. The primary objective was to assess the safety and efficacy of $\mathrm{CP}$ in moderately ill patients with primary end points being progression to severe acute respiratory distress syndrome, all-cause mortality at 28 days and secondary end points being symptomatic-radiologic-clinical resolution, hospital stay, viral load, antibody titer, and biomarker levels (C-reactive protein, interleukin-6, ferritin). Control group received standard care (symptomatic treatment, antiretrovirals, immunomodulators, anticoagulants, etc.). Although there was symptomatic improvement and seronegative conversion, reduction in 28-day mortality was not achieved. ${ }^{42}$ Studies with longer duration of follow-up (3 months), on different study population (critically ill), survey-based study on the knowledge/practices concerning $\mathrm{CP}$ usage are all ongoing ${ }^{40}$ and published results are expected soon. Delhi developed the first plasma bank in the country on June 2, 2020 followed by the second one on July 14, 2020 in two major COVID-19 hospitals. ${ }^{43,44}$ Maharashtra has launched Project PLATINA, involving 21 centers to enroll 5,000 critically ill patients. ${ }^{45}$ 


\section{Indian Challenges}

Although $\mathrm{CP}$ is considered a cheaper/quicker alternative to other options, it is still dear and fancy for developing countries. India has a long way to go due to challenges ranging from lack of guidelines, apheresis centers, and testing kits. ${ }^{46}$ The major challenges are discussed in the following text.

\section{Lack of Guidelines}

As of date, India has no guidelines regarding collection, testing, storage, and use of $\mathrm{CP}$. Addressing the importance of research, the ICMR-Bioethics unit released a guideline for undertaking quick research without compromising validity and ethics. ${ }^{47}$ This document highlights the importance of prioritizing COVID-19-related research, patient/donor confidentiality (circulating pictures might create nuisance due to stigma associated with disease), consent (CP is an experimental drug), equitable patient enrolment, nonremuneration, coverage for research-related injuries, accessibility of research findings, and biosafety precautions.

\section{Donor Recruitment}

The success of CP depends on number of donors coming forward to donate. In the current setup where inventory is already dipping, ${ }^{46}$ it is sad to observe when blood banks repeatedly call donors to receive no response in return. Hence, counselling must start at in-patient level, emphasizing their moral responsibility to donate $\mathrm{CP}$ post-recovery. A dedicated team should tie up with COVID-19 centers to recruit potential donors. Use of social media can have huge impact. Robust mass tracking/tracing for donors should be considered after weighing the public health need versus privacy issues. Guideline for transfer of $\mathrm{CP}$ from one blood bank if established can ease the availability of CP to peripheral centers.

\section{Donor Selection}

$\mathrm{CP}$ obtained in India is majorly through directed or replacement donation who may not completely reveal the history under pressure to help the patient. This is riskier compared with voluntary donation due to higher risk of transmitting infections to the recipient (especially without nucleic acid testing) and health care workers (respiratory shedding of SARS-CoV-2). Hence, it is better not just to rely on the donor claiming to be asymptomatic.

Female donor parity is again a topic of controversy. Although the FDA and European guidelines recommend CP collection from parous females only if they are negative for human leukocyte antigen antibodies, such testing facilities are not available in Indian blood banks. Hence, the decision to defer parous female donors must be weighed considering the rare incidence of transfusion-associated lung injury) versus $\mathrm{CP}$ availability.

\section{Donor Testing}

Although studies have observed respiratory shedding of virus from 13 to 29 days of symptom recovery, ${ }^{48}$ no one exactly knows when the shedding stops. Most countries follow a policy of recruiting donors after 14 days of recovery. But with regard to testing, some countries recommend a negative nucleic acid test before donating, sometimes even two negative results obtained 24 hours apart (prevent exposure to health-care workers) and some allow donation after 28 days even without testing (-Table $\mathbf{1}$ ). Longer duration post-recovery ensures complete resolution and adequate dose of antibody.

Reverse transcription polymerase chain reaction (RT-PCR), enzyme-linked immunosorbent assay (ELISA), and rapid diagnostic test (RDT) are the common tests used to detect the presence of viral antigen. Apart from nasopharyngeal swab (preferred sample), others include oropharyngeal swab, bronchoalveolar lavage, tracheal aspirate, sputum, lung tissue (autopsy), blood, urine, and stool. ${ }^{39}$ ICMR has advised the use of FDA-approved in-vitro-diagnostic-kits. ${ }^{49}$ Since RT-PCR is restricted to higher level centers, has longer turnover time, and is costlier, the use of RDTs have been approved. ${ }^{50}$ The availability and affordability of these testing kits have improved. ${ }^{51}$ It is important to mention the test-seeking behaviors of anxious individuals who may/may not have contracted the infection. ${ }^{52}$ Having said that, the reliability of donor information on infection resolution is questionable. Hence, the decision on whether or not to test donors and if yes, which test to be done (rapid/nucleic-acid-based) and the number of tests required should be decided accordingly. For example, donor recruited from the same hospital/with reliable documented test result can directly go through the donation process. The chance of false positives/negatives must also be kept in mind before deciding on the testing modality. Routine testing (blood grouping, infectious markers) and quality-checks have to be adhered to.

\section{Antibody Titration}

Various controversies on minimal titer, time of collection, and type of antibody/isotype/subclass to be measured exist. Till date studies claim that titers increase from day 10 to 15 and become steady after. ${ }^{53}$ The minimal titer requirement varies from country-to-country ( - Table 1 ). Although neutralizing antibodies are the focus, their titers are variable (especially after mild symptoms). ${ }^{54,55}$ Another theory suggests that high titer of immunoglobulin (IgM) might not be safe, as it indicates recent/current infection. Hence, it is safe to measure both IgM and IgG levels. Other hurdles include availability of testing equipment and lack of standardization. The gold standard test, namely plaque-reduction-neutralization-assay requires biosafety level-3 setup, has a longer turnaround time and requires expertise to perform. Hence, developing countries predominantly use ELISA. But there are challenges in the availability and procurement of these testing kits. Addressing all these barriers, none of the guidelines have made it mandatory to test for antibody titer before transfusion, although they suggest sample storage for later testing that will help in correlating the therapeutic effect ( - Table 1). In other words, the sole purpose of $\mathrm{CP}$ transfusion in itself need not be confirmed before transfusion. This might lead to unwanted side effects with no benefit probably. 
Table 1 A comparison of major guidelines

\begin{tabular}{|c|c|c|c|}
\hline Criteria & US-FDA ${ }^{32}$ & European $^{70}$ & $\mathrm{ISBT}^{71}$ \\
\hline Donor-selection & $\begin{array}{l}\text { 1. Routine donor eligibility } \\
\text { 2. } 14 \text { days following recovery } \\
\text { 3. Documented positive diagnos- } \\
\text { tic test (nasopharyngeal swab) } \\
\text { at the time of illness or positive } \\
\text { serological test after recovery } \\
\text { 4. Female donors who have } \\
\text { been tested as negative for } \\
\text { HLA antibodies since their last } \\
\text { pregnancy }\end{array}$ & $\begin{array}{l}\text { 1. Routine donor selection guidelines } \\
\text { Direct recruitment from National } \\
\text { COVID-19 registry and not restricted to } \\
\text { social media/calls } \\
\text { 2. Documented prior RT-PCR positive or } \\
\text { current antibody-positive irrespective of } \\
\text { previous symptoms } \\
\text { 3. } 28 \text { days following recovery or } 14 \text { days } \\
\text { if there is use of pathogen-reduc- } \\
\text { tion-techniques, negative RT-PCR from } \\
\text { upper-respiratory-tract sample and } \\
\text { positive serology in donors who never } \\
\text { developed symptoms/never had RT-PCR } \\
\text { done } \\
\text { 4. No history of blood transfusion and } \\
\text { female donors who have been tested as } \\
\text { negative for HLA antibodies since their } \\
\text { last pregnancy } \\
\text { 5. Donors donating more than once should } \\
\text { test for antibody titers }\end{array}$ & $\begin{array}{l}\text { 1. Local regulations in line } \\
\text { with donor selection during } \\
\text { pandemic }{ }^{74} \\
\text { 2. Confirm recovery by physi- } \\
\text { cal examination and testing } \\
\text { Documented and traceable } \\
\text { history, symptoms, treatment, } \\
\text { and date of resolution } \\
\text { 3. } 28 \text { days following recovery } \\
\text { ( } 2 \text { negative test result by nucle- } \\
\text { ic-acid-testing on nasopharyn- } \\
\text { geal swabs } 24 \text { hours apart) } \\
\text { 4. Preferably female donors who } \\
\text { have never been pregnant } \\
\text { (including abortions) } \\
\text { 5. Repeat donations complying } \\
\text { local regulations }\end{array}$ \\
\hline Antibody-titer & $\begin{array}{l}\text { 1. If available } \\
\text { 2. Minimal titer 1:160 recom- } \\
\text { mended, 1:80 acceptable } \\
\text { 3. If not, store sample for later } \\
\text { testing }\end{array}$ & $\begin{array}{l}\text { 1. Strongly recommended to measure } \\
\text { antibody titers before/after donation/ } \\
\text { after processing } \\
\text { 2. No robust cutoff } \\
>160 \text { recommended by Italian Society }{ }^{60} \\
\text { If no antibody detected, divert for rou- } \\
\text { tine transfusion/fractionation } \\
\text { 3. Additional sample saving (irrespective } \\
\text { of testing) } \\
\text { 4. For repeat donation, donors with higher } \\
\text { antibody titer preferred }\end{array}$ & $\begin{array}{l}\text { 1. If feasible } \\
\text { 2. Samples stored at }-80^{\circ} \mathrm{C} \text { for } \\
\text { testing later }\end{array}$ \\
\hline Collection & $\begin{array}{l}\text { 1. Licensed centers } \\
\text { 2. Label mentioning “Caution: } \\
\text { New Drug-Limited by Federal } \\
\text { law to investigational use," } \\
\text { along with ISBT-128 labeling }\end{array}$ & $\begin{array}{l}\text { 1. Apheresis whenever possible; whole } \\
\text { blood can also be collected; notify seri- } \\
\text { ous donor reactions } \\
\text { 2. Labeled as COVID-19 convalescent } \\
\text { plasma/blood } \\
\text { 3. Final product split to } 200 \mathrm{~mL} \text { units } \\
\text { 4. Pathogen reduction need not be applied } \\
\text { in specific to CP alone }\end{array}$ & $\begin{array}{l}\text { 1. Certified establishments with } \\
\text { approved collection equipment } \\
\text { and trained staff } \\
\text { 2. Clearly labeled } \\
\text { 3. } 200-600 \mathrm{~mL} \text { (without } \\
\text { anticoagulant) } \\
\text { 4. Pathogen inactivation preferred }\end{array}$ \\
\hline Storage & $\begin{array}{l}\text { Stored within } 8 \text { hours of collec- } \\
\text { tion at }-18^{\circ} \mathrm{C} \text { or colder ( } 1 \text {-year } \\
\text { expiry) }\end{array}$ & $\begin{array}{l}\text { Routine guidelines of storage in dedicated } \\
\text { location }^{72}\end{array}$ & $\begin{array}{l}\text { Freeze as soon as possible } \\
\left(-20^{\circ} \mathrm{C} \text { or colder }\right)\end{array}$ \\
\hline Patient-selection & $\begin{array}{l}\text { 1. Clinical trials } \\
\text { 2. Expanded access } \\
\text { 3. Emergency treatment }\end{array}$ & $\begin{array}{l}\text { 1. Laboratory confirmed positive } \\
\text { in-patients } \\
\text { 2. Preferable to enroll in trial and share } \\
\text { coded data } \\
\text { 3. Transfused within } 7 \text { to } 14 \text { days of symp- } \\
\text { tom onset }{ }^{60}\end{array}$ & $\begin{array}{l}\text { Preferably through organized } \\
\text { research studies only }\end{array}$ \\
\hline Transfusion & As per trial protocols & $\begin{array}{l}\text { 1. Aim to transfuse } \mathrm{CP} \text { with highest anti- } \\
\text { body titer } \\
\text { 2. Transfuse } 8-10 \mathrm{~mL} / \mathrm{kg} \text {, maximum } 600 \\
\mathrm{~mL} / \text { day and up to } 3 \text { consecutive days }{ }^{60} \\
\text { 3. Absolute contraindication: IgA- } \\
\text { deficiency; record all side effects }{ }^{60}\end{array}$ & $\begin{array}{l}\text { 1. Hospital plasma transfusion } \\
\text { protocol } \\
\text { 2. Initial dose of } 200 \mathrm{~mL} \text { followed } \\
\text { by additional (one or two) } 200 \\
\mathrm{~mL} \text { doses according to tolerance } \\
\text { and disease severity } \\
\text { 3. ABO compatible } \\
\text { 4. Preferable to transfuse CP of } 2 \\
\text { different donors } \\
\text { 5. Strict hemovigilance of recipient } \\
\text { (pre- and post-transfusion sam- } \\
\text { ple to be stored) }\end{array}$ \\
\hline
\end{tabular}

Abbreviations: COVID-19, coronavirus disease 2019; CP, convalescent plasma; HLA, human leukocyte antigen; IgA, immunoglobulin A; ISBT-128, International Society of Blood Transfusion; RT-PCR, reverse transcription polymerase chain reaction; US-FDA, U.S. Food and Drug Administration. 


\section{Match Donor with Patients}

Ensuring selection of right donor, harvesting product at right time, allotting to right patient, and transfusing at right time are a cumbersome task. Use of health information technology will help simplify this process. A team of informatics experts from Malaysia and Iraq has come up with a fully automated-computing-solution-framework, ${ }^{56}$ which shall compile the national recommendation for $\mathrm{CP}$, donor parameters (blood group, viral marker status, antibody titer, etc.) and patient parameters (serology, blood group, disease severity). By multi-criteria-decision-making software, which will weigh and outweigh various combinations of donor-patient, a said product will be allotted to a said patient by subjective-objective-decision-by-opinion-score-method just by the click of a mouse. Such programmed software can help in simplifying the work of doctors.

\section{Harvest}

Only licensed blood centers with trained staff should collect CP following good manufacturing practices ( - Table $\mathbf{1}$ ). India is still at a toddler level, as even the tertiary centers (government funded) in many states do not have a functional apheresis unit due to higher cost and required expertise. ${ }^{57,58}$ Procuring cell-separators and training of staff had to be fastened to enroll more blood banks to participate in trials. The ISBT-working-group-on-convalescent-plasma has suggested to keep the $\mathrm{CP}$ collection to a restricted area of blood center. Mobile collections to be done in areas only where a significant number of individuals have been cured. $^{52}$ Preliminary telephonic screening will prevent unnecessary exposure of health-care workers. Plasma from whole blood collection can be considered in resource-poor setups ( - Table 1 ). There is no national guideline till date on collection volume for which other guidelines are to be followed (-Table 1).

\section{Pathogen-Reduction Technologies}

SARS-CoV-2 is a large ( $120 \mathrm{~nm}$ ) lipid-enveloped virus, which makes it susceptible to pathogen-reduction-technologies (PRT) (solvent-detergent, pasteurization, dry-heat, nanofiltration). Studies on the effect of PRT on SARS-CoV-2 have promised results. ${ }^{59}$ There is enough evidence that SARS-CoV-2 is not transmitted by blood. Hence, the unavailability of these techniques will not pose any increased risk of transfusion-transmitted infections.

\section{Recipient Monitoring}

No strict guidelines on the volume to be transfused exist. Italian society suggests transfusion of 8 to $10 \mathrm{~mL} / \mathrm{kg}$ once a day up to 3 days consecutively. ${ }^{60}$ ISBT working party suggests a minimum of $200 \mathrm{~mL} .{ }^{52}$ Actual dosage can only be calculated after knowing the bioavailability of the transfused product. Studies to conclude the optimal dose and best therapeutic window are ongoing.

No concerning side effects were observed till date apart from those associated with routine plasma transfusion (febrile reactions, allergic episodes) that can easily be resolved by symptomatic management and slowing of transfusion rate. Although in theory patients with pre-existing lung injury can have more severe transfusion-related respiratory side effects and vice versa, ${ }^{61}$ such findings have not yet been found in COVID-19 patients. Blood group matching is of critical importance in blood transfusion, but it is not the case in plasma. The occurrence of a hemolytic transfusion reaction is estimated to be approximately 1 in 2,000 to 9,000 (anti-A, B IgM titers $>100$ can cause hemolysis). ${ }^{62}$ But, the national guidelines on the use of $\mathrm{CP}$ as an off-label drug recommend $\mathrm{ABO}$ compatible usage only. ${ }^{39}$ This hugely impacts the $\mathrm{CP}$ availability in relatively rarer blood groups.

Other risks such as aggravation of hyperimmune attacks exist, ${ }^{63}$ emphasizing the importance of timing of administration. The exact timing of administration of $\mathrm{CP}$ still remains controversial. Transfusing CP in the earlier phase of disease (when the body has not produced antibody) will reduce repeated immune system stimulation, thereby preventing cytokine storm. On the other hand, transfusing at later phase of the disease might have a better effect as the patient will have a higher viral load. Although transfusion from two different donors might be beneficial, there exists a risk of multiple exposures to immunogenic antibodies and blood transmitted infections. Strict surveillance and reporting on adverse effects following transfusion, clinical, laboratory, and radiologic changes are necessary to obtain conclusive data. But in India, only 368 out of 3,108 blood banks have enrolled in the National Hemovigilance Program. ${ }^{64}$

\section{Privatization and Misuse}

In India, selling or donating blood in exchange of money is illegal under the NBTC Services Act 2007. Those convicted may face 3 months sentencing to jail with fine. ${ }^{65}$ Although centers are intolerant toward paid/professional donation, a crisis such as the current situation will be misused by opportunists. ${ }^{66}$ Such behavior can only be prevented by having a voluntary plasma bank.

In absolute contrast to the Act, ${ }^{65}$ the Karnataka government has announced Rs. 5,000 incentive for CP donors. Paid donation is a transparent and lawful practice in the West. But, in a country like India, paid donation leads to high rate of transfusion-transmitted infections, repeat donation before 3 months, and looting of the patient's family. Such monetary promotions may be beneficial in the short term, but in the long term may be unwelcome. ${ }^{67}$

\section{Immunoglobulin Preparation}

Diversion of $\mathrm{CP}$ to produce HIIG by pooling and fractionation can be done. Studies comparing CP with HIIG are ongoing. ${ }^{31}$ There are advantages (concentrated product, lower chance of transfusion reactions, $A B O$ nonspecific transfusion) and disadvantages (costly, longer preparation time) of HIIG as compared with CP. ${ }^{11,68}$ With an annual collection of 10 to 11 million units annually, India has only four fractionation centers, with importing majority of the fractional products. ${ }^{58,69}$ Also, the availability of $\mathrm{CP}$ is just enough to fulfil the patient requirement. There is a long way to go before India can divert excess $\mathrm{CP}$ for HIIG manufacturing. 


\section{Conclusion}

The right and wrong debate in the use of CP is yet to be solved and generalization of published evidence is not advisable. The low incidence/severity of CP-related adverse events and lack of evidence on other therapies have promoted the use of $\mathrm{CP}$ as an off-label drug. But its widespread use must await high-quality evidence. Despite the ocean of published and ongoing research on $\mathrm{CP}$, it is still alien to many parts of the developing countries. Although in the right path, the building enthusiasm must be dealt cautiously to prevent the promotion of professional/paid donation.

\section{Authors' Contributions}

P.J.A. contributed to developing the concept and design of the review, definition of intellectual content, literature search, and manuscript preparation, editing, and review. K.K. contributed to developing the concept of the review, definition of intellectual content, literature search, and manuscript editing, and review. A.S. contributed to developing the concept of the review, literature research, and manuscript editing, and review. He is also the guarantor of the article.

\section{Conflict of Interest}

Nil.

\section{References}

1 Lu R, Zhao X, Li J, et al. Genomic characterisation and epidemiology of 2019 novel coronavirus: implications for virus origins and receptor binding. Lancet 2020;395(10224) :565-574

2 Schoeman D, Fielding BC. Coronavirus envelope protein: current knowledge. Virol J 2019;16(1):69

3 Chan JF-W, Kok K-H, Zhu Z, et al. Genomic characterization of the 2019 novel human-pathogenic coronavirus isolated from a patient with atypical pneumonia after visiting Wuhan. Emerg Microbes Infect 2020;9(1):221-236

4 WHO. Coronavirus disease 2019 (COVID- 19) situation report. 2020 Available from: https://www.who.int/docs/defaultsource/coronaviruse/ 20200312-sitrep-52-covid-19.pdf?sfvrsn=e2bfc9c0_2. Accessed Oct 25, 2020

5 Huang C, Wang Y, Li X, et al. Clinical features of patients infected with 2019 novel coronavirus in Wuhan, China. Lancet 2020;395(10223):497-506

6 Wang D, Hu B, Hu C, et al. Clinical characteristics of 138 hospitalized patients with 2019 novel coronavirus-infected pneumonia in Wuhan, China. JAMA 2020;323(11):1061-1069

7 Chen G, Wu D, Guo W, et al. Clinical and immunologic features in severe and moderate forms of coronavirus disease. J Clin Invest 2020;130(5):2620-2629

8 Han H, Yang L, Liu R, et al. Prominent changes in blood coagulation of patients with SARS-CoV-2 infection. Clin Chem Lab Med 2020;58(7):1116-1120 (ahead-of-print)

9 Zhang J, Xie B, Hashimoto K. Current status of potential therapeutic candidates for the COVID-19 crisis. Brain Behav Immun 2020;87:59-73

10 Zhang L, Liu Y. Potential interventions for novel coronavirus in China: a systematic review. J Med Virol 2020;92(5):479-490

11 Mair-Jenkins J, Saavedra-Campos M, Baillie JK, et al. Convalescent Plasma Study Group. The effectiveness of convalescent plasma and hyperimmune immunoglobulin for the treatment of severe acute respiratory infections of viral etiology: a systematic review and exploratory meta-analysis. J Infect Dis 2015;211(1):80-90
12 Casadevall A, Scharff MD. Serum therapy revisited: animal models of infection and development of passive antibody therapy. Antimicrob Agents Chemother 1994;38(8):1695-1702

13 Schoofs T, Klein F, Braunschweig M, et al. HIV-1 therapy with monoclonal antibody 3BNC117 elicits host immune responses against HIV-1. Science 2016;352(6288):997-1001

14 Lünemann JD, Nimmerjahn F, Dalakas MC. Intravenous immunoglobulin in neurology-mode of action and clinical efficacy. Nat Rev Neurol 2015;11(2):80-89

15 Casadevall A, Dadachova E, Pirofski LA. Passive antibody therapy for infectious diseases. Nat Rev Microbiol 2004;2(9):695-703

16 Cheng Y, Wong R, Soo YO, et al. Use of convalescent plasma therapy in SARS patients in Hong Kong. Eur J Clin Microbiol Infect Dis 2005;24(1):44-46

17 Ko J-H, Seok H, Cho SY, et al. Challenges of convalescent plasma infusion therapy in Middle East respiratory coronavirus infection: a single centre experience. Antivir Ther 2018;23(7):617-622

18 Arabi YM, Hajeer AH, Luke T, et al. Feasibility of using convalescent plasma immunotherapy for MERS-CoV infection, Saudi Arabia. Emerg Infect Dis 2016;22(9):1554-1561

19 Florescu DF, Kalil AC, Hewlett AL, et al. Administration of brincidofovir and convalescent plasma in a patient with Ebola virus disease. Clin Infect Dis 2015;61(6):969-973

20 Organization WH. Use of Convalescent Whole Blood or Plasma Collected from Patients Recovered from Ebola Virus Disease for Transfusion, as an Empirical Treatment during Outbreaks. 2014 (version 1.0) Available from: https://www.euro.who. int/_data/assets/pdf_file/0011/268787/Use-of-ConvalescentWhole-Blood-or-Plasma-Collected-from-Patients-Recoveredfrom-Ebola-Virus-Disease-for-Transfusion,-as-an-EmpiricalTreatment-during-Outbreaks-Eng.pdf. Accessed Oct 25, 2020

21 Beigel JH, Tebas P, Elie-Turenne M-C, et al. IRC002 Study Team. Immune plasma for the treatment of severe influenza: an open-label, multicentre, phase 2 randomised study. Lancet Respir Med 2017;5(6):500-511

22 Enria DA, Briggiler AM, Fernandez NJ, Levis SC, Maiztegui JI. Importance of dose of neutralising antibodies in treatment of Argentine haemorrhagic fever with immune plasma. Lancet 1984;2(8397):255-256

23 Shen C, Wang Z, Zhao F, et al. Treatment of 5 critically ill patients with COVID-19 with convalescent plasma. JAMA 2020;323(16):1582-1589

24 Duan K, Liu B, Li C, et al. Effectiveness of convalescent plasma therapy in severe COVID-19 patients. Proc Natl Acad Sci U S A 2020;117(17):9490-9496

25 Li L, Zhang W, Hu Y, et al. Effect of convalescent plasma therapy on time to clinical improvement in patients with severe and life-threatening COVID-19: a randomized clinical trial. JAMA 2020;324(5):460-470

26 Liu STH, Lin HM, Baine I, Wajnberg A, Gumprecht JP, Rahman F, et al. Convalescent plasma treatment of severe COVID-19: a propensity score-matched control study. Nat med 2020;26:1708-13

27 Zeng Q-L, Yu Z-J, Gou J-J, et al. Effect of convalescent plasma therapy on viral shedding and survival in patients with coronavirus disease 2019. J Infect Dis 2020;222(1):38-43

$28 \mathrm{Uhr}$ JW, Baumann JB. Antibody formation. I. The suppression of antibody formation by passively administered antibody. J Exp Med 1961;113:935-957

29 Tirado SMC, Yoon K-J. Antibody-dependent enhancement of virus infection and disease. Viral Immunol 2003;16(1):69-86

30 Bloch EM, Shoham S, Casadevall A, et al. Deployment of convalescent plasma for the prevention and treatment of COVID-19. J Clin Invest 2020;130(6):2757-2765

31 Valk SJ, Piechotta V, Chai KL, et al. Convalescent plasma or hyperimmune immunoglobulin for people with COVID-19: a rapid review. Cochrane Database Syst Rev 2020;5:CD013600 
32 Services USDoHaH. Administration FaD, Research CfBEa. Investigational COVID-19 convalescent plasma. 2020 [updated May 1] Available from: https://www.fda.gov/media/136798/ download. Accessed Oct 25, 2020

33 Maor Y, Cohen D, Paran N, Israely T, Ezra V, Axelrod O, et al. Compassionate use of convalescent plasma for treatment of moderate and severe pneumonia in COVID-19 patients and association with IgG antibody levels in donated plasma. EClinicalMedicine 2020;26:100525

34 Salazar E, Perez KK, Ashraf M, et al. Treatment of coronavirus disease 2019 (COVID-19) patients with convalescent plasma. Am J Pathol 2020;190(8):1680-1690

35 Joyner MJ, Bruno KA, Klassen SA, et al. Safety update: COVID-19 convalescent plasma in 20,000 hospitalised patients. Mayo Clin Proc 2020;95(9):1888-1897

36 Rasheed AM, Fatak DF, Hashim HA, et al. The therapeutic potential of convalescent plasma therapy on treating critically-ill COVID-19 patients residing in respiratory care units in hospitals in Baghdad, Iraq. Infez Med 2020;28(3):357-366

37 Erkurt MA, Sarici A, Berber İ, Kuku İ, Kaya E, Özgül M. Life-saving effect of convalescent plasma treatment in covid-19 disease: clinical trial from eastern Anatolia. Transfus Apheresis Sci 2020;102867:102867

38 National Blood Transfusion Council MoHfW. National Guideline to Blood Transfusion Services in India in Light of COVID-19 Pandemic. 2020 Available from: https://www. mohfw.gov.in/pdf/2ndNBTCGuidanceinLightofCOVID19Pandemic.pdf. Accessed Oct 25, 2020

39 CDSC. Information on Convalescent Plasma in COVID-19. 2020 Available from: https://cdsco.gov.in/opencms/resources/ UploadCDSCOWeb/2018/UploadPublic_NoticesFiles/ MoHFW\%20Convalescent\%20Plasma\%20in\%20COVID\%20 draft.pdf. Accessed Oct 25, 2020

40 Central Trials Registry - India. http://ctri.nic.in/Clinicaltrials/ login.php. Accessed Oct 25, 2020

41 Research ICoM. Phase II Convalescent Plasma Study: Update. 2020 Available from: https://www.icmr.gov.in/pdf/covid/techdoc/Convalsecent_plasma_update.pdf. Accessed Oct 25, 2020

42 Agarwal A, Mukherjee A, Kumar G, Chatterjee P, Bhatnagar T, Malhotra P, et al. Convalescent plasma in the management of moderate COVID-19 in India: an open-label parallel-arm phase II multicentre randomized controlled trial (PLACID Trial). DOI: 10.1101/2020.09.03.20187252. Accessed Oct 25, 2020

43 Delhi govt. launches India's first plasma bank at ILBS Hospital. The Hindu; July 3, 2020. Available at: article31969629.ece. Last accessed: May 20, 2021

44 Kejriwal launches Delhi's second plasma bank for COVID-19 patients at LNJP Hospital. Hindustan Times; July 14, 2020. Available at: story-PA4uZiMToAAYWWsx0P7LEP.html. Last accessed: May 20, 2021

45 Uddhav opens plasma therapy trial centre. The Hindu; June 30, 2020. Available at: article31949321.ece. Last accessed on: May 20, 2021

46 Arcot JP, Kumar K, Mukhopadhyay T, Subramanian A. Potential challenges faced by blood bank services during COVID-19 pandemic and their mitigative measures: the Indian scenario [published online ahead of print, $2020 \mathrm{Jul} 16$ ]. Transfus Apher Sci 2020;102877

47 Research ICoM. National Guideline for Ethics Committees Reviewing Biomedical \& Health Research, during Covid-19 Pandemic. April 2020 Available from: https://ethics. ncdirindia.org/asset/pdf/EC_Guidance_COVID19.pdf. Accessed Oct 25, 2020

48 Wang W, Xu Y, Gao R, et al. Detection of SARS-CoV-2 in different types of clinical specimens. JAMA 2020;323(18):1843-1844

49 Research ICoM. Advisory on Use of Rapid Antigen Detection Test for COVID-19. June 14, 2020 Available from: https://
www.icmr.gov.in/pdf/covid/strategy/Advisory_for_rapid_ antigen_test14062020.pdf. Accessed Oct 25, 2020

50 MOHFW. Protocol for Rapid Antibody test. 2020 Available from: https://www.mohfw.gov.in/pdf/ProtocolRapidAntibodytest. pdf. Accessed Oct 25, 2020

51 COVID-19 in India: the dangers of false optimism. The Lancet. Editorial. 2020;396:867

52 Bloch EM, Goel R, Wendel S, Burnouf T, Al-Riyami AZ, Ang AL, et al. Guidance for the procurement of COVID-19 convalescent plasma: differences between high and low-middle income countries. Vox Sang 2020;13:10.1111/vox.1290

53 Wu F, Wang A, Liu M, Wang Q, Chen J, Xia S, et al. Neutralizing antibody responses to SARS-CoV-2 in a COVID-19 recovered patient cohort and their implications. MedRxiv 2020

54 Robbiani DF, Gaebler C, Muecksch F, et al. Convergent antibody responses to SARS-CoV-2 infection in convalescent individuals. bioRxiv 2020;2020.05.13.092619

55 Case JB, Rothlauf PW, Chen RE, Liu Z, Zhao H, Kim AS, et al. Neutralizing antibody and soluble ACE2 inhibition of a replication-competent VSV-SARS-CoV-2 and a clinical isolate of SARS-CoV-2. Cell Host Microbe 2020;28:475-85.e5

56 Albahri OS, Al-Obaidi JR, Zaidan AA, et al. Helping doctors hasten COVID-19 treatment: Towards a rescue framework for the transfusion of best convalescent plasma to the most critical patients based on biological requirements via $\mathrm{ml}$ and novel MCDM methods. Comput Methods Programs Biomed 2020;196:105617

57 Muddegowda PH, Lingegowda JB, Jeyakumar JD, Velusamy S, Ramachandran T. Therapeutic applications of red cell exchange in apheresis: a review. National J Basic Med Sci. 2015;5:2-4

58 Ajmani RS. Indian plasma fractionation industry: challenges and opportunities. Ann Blood 2018;3:30

59 Ragan I, Hartson L, Pidcoke H, Bowen R, Goodrich R. Pathogen reduction of SARS-CoV-2 virus in plasma and whole blood using riboflavin and UV light. PLoS One 2020;15(5):e0233947

60 Accorsi P, Berti P, de Angelis V, De Silvestro G, Mascaretti L, Ostuni A; Italian Society for Transfusion Medicine Immunohaematology (SIMTI) Italian Society for Hemapheresis cell Manipulation (SIdEM). Position paper on the preparation of immune plasma to be used in the treatment of patients with COVID-19. Transfus Apheresis Sci 2020;59(4):102817

61 Benson AB, Moss M, Silliman CC. Transfusion-related acute lung injury (TRALI): a clinical review with emphasis on the critically ill. Br J Haematol 2009;147(4):431-443

62 Berséus O, Boman K, Nessen SC, Westerberg LA. Risks of hemolysis due to anti-A and anti-B caused by the transfusion of blood or blood components containing ABO-incompatible plasma. Transfusion 2013;53(Suppl 1) :114S-123S

63 Marano G, Vaglio S, Pupella S, et al. Convalescent plasma: new evidence for an old therapeutic tool? Blood Transfus 2016;14(2):152-157

64 Bisht A, Marwaha N, Kaur R, Gupta D, Singh S. Haemovigilance Programme of India: analysis of transfusion reactions reported from January 2013 to April 2016 and key recommendations for blood safety. Asian J Transfus Sci 2018;12(1):1-7

65 Sinha K. Professional blood donors may soon be jailed. The Times of India. November 28, 2020

66 Verma U. Covid-19: Lakhs being offered for plasma donations. The Times of India. July 11, 2020

67 Marwaha N. Voluntary blood donation in India: achievements, expectations and challenges. Asian J Transfus Sci 2015;9(Suppl 1) :S1-S2

68 Hung IFN, To KK, Lee C-K, et al. Hyperimmune IV immunoglobulin treatment: a multicenter double-blind randomized controlled trial for patients with severe 2009 influenza A(H1N1) infection. Chest 2013;144(2):464-473 
69 Bajaj A. Available from: https://www.investindia.gov.in/teamindia-blogs/overview-blood-plasma-fractionation-india. March 13, 2020 Accessed Oct 25, 2020

70 SAFETY ECD-GFHAF. An EU programme of COVID-19 convalescent plasma collection and transfusion. 2020 Available from: https://ec.europa.eu/health/sites/ health/files/blood_tissues_organs/docs/guidance_plasma_ covid19_en.pdf. Accessed Oct 25, 2020

71 Epstein J, Burnouf T. Points to consider in the preparation and transfusion of COVID-19 convalescent plasma. Vox Sang 2020;115(6):485-487
72 CFR - Code of Federal Regulations Title 21, U.S. Food and Drug Administration. https://www.accessdata.fda.gov/scripts/cdrh/ cfdocs/cfffr/cfrsearch.cfm. Accessed Oct 25, 2020

73 Transfusion ECoB. Guide to the preparation, use and quality assurance of blood components. 2017 Available from: http:// ipst.pt/files/IPST/INFORMACAO_DOCUMENTACAO/EDQM_ Blood_transfusion_guide_19ed_2017_pub_PUBSD-89.pdf. Accessed Oct 25, 2020

74 (BRN) WBRN. Donor selection in case of pandemic situations. 2007 Available from: https://www.who.int/bloodproducts/ brn/DonorSelectionincaseofPandemicSituations.pdf?ua=1. Accessed Oct 25, 2020 